\title{
Review on Phytochemicals and Pharmacological Studies of Allium cepa (Onion)
}

\author{
Battagani Deepthi*, Jada Naga Lakshmi, Rayadurgam Naveen \\ Department of Pharmacology, Chalapathi Institute of Pharmaceutical Sciences, Lam, Chalapathi Nagar, Guntur-522034, India. \\ *Corresponding author's E-mail: deepthi1076@gmail.com
}

Received: 22-02-2021; Revised: 24-04-2021; Accepted: 02-05-2021; Published on: 15-05-2021.

\begin{abstract}
In present days, herbal medicines have gained importance with both medical and economic implications. Throughout the world raised concerns of quality, safety and efficacy. Onion has been valued as a food, medicinal plant since ancient times and widely cultivated. And known as "Queen of the kitchen". Due to its flavor, aroma, unique taste, medicinal properties of its compound. And acts as food which provides a good amount of nutrients, immunity to the body, helps in treating high cholesterol, diabetes, joint disorders, digestive ailments, loss of appetite, gallbladder diseases, angina pectoris, high blood pressure, atherosclerosis, sore throat, asthma, bronchitis, cough, intestinal gas and intestinal worms as therapeutic agent. Different biological properties, such as, antioxidants, antiinflammatory, anti-cholesterol, antihypertensive, anti-cancer, anti-arthritic, anti-bacterial, bronchodilator, expectorant, antispasmodic, antiseptic, carminative, anti-coagulant, fibrinolytic, anti-helminthic, anti-platelet, hepatoprotective activity, anti-diabetic, anti-viral, cardiovascular protective, anti-microbial, neuro protective, anti-genotoxic and anti-mutagenic effect, anti-pyretic, analgesic, and various other biological activities. Wide spectrum of biological activities of onion makes it as a potential medicinal and therapeutic agent.
\end{abstract}

Keywords: Allium cepa, Pharmacological and therapeutic Activities.

\section{QUICK RESPONSE CODE $\rightarrow$ \\ DOI: \\ 10.47583/ijpsrr.2021.v68i01.015}

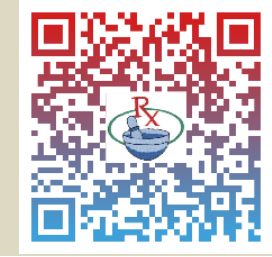

DOI link: $\underline{\text { http://dx.doi.org/10.47583/ijpsrr.2021.v68i01.015 }}$

\section{INTRODUCTION}

A . cepa (Onion) is used as a multipurpose food plant and as traditional Indian spices with great health significance. Onions are pungent when they are chopped and contains chemical substances which irritates the eyes ${ }^{1}$. Onion is consumed in order to obtain its putative nutritional along with health benefits, it has flavor, aroma, unique taste, medicinal properties called as "Queen of the kitchen" and using form centuries ${ }^{2,3}$. Allium, a huge genus carrying 4000 species. Disseminated throughout the temperate regions near the world. Including Europe, Asia, North America, Africa. The name arise in all probability was taken from the Latin unus which means as "one". The Romans inaugurated the onion up to Britain, starting with where it may be conveyed to Americans ${ }^{4}$. The dignified physician Hippocrates advised onion as an emmenagogue, diuretic, laxative. Also used for the medication of healing putrid wounds, outer, also for pneumonia ${ }^{5}$. Other names for Allium cepa are in English as Onion, Tamil as Vaengayam, Malayalam as Savala, Telugu as Ullipayalu, Kannada as Ulligadde, Hindi and Punjabi as Payaz, Bengali as piyaz, Gujarati as Dungri, Konkani as Sawalo, Marathi as Kandaa, Oriya as piaja ${ }^{6}$. Onion is a production, produced world widely and extensively grown biennial bulb crop. Production of onion in India 23,262 tons in 2017-18, and 23,610 tons in $2018-19^{7}$. Onions used as a food stuff usually by cooking, or a part of prepared savory dish or as vegetable. However, it also eaten as raw in pickles and chutneys. The roots of onion bulb are used to treat the flatulence, diarrhoea, alleviate night blindness, urinary tract infections, it also relieves nausea, fever, cough, stimulate appetite, fortify semen, to alleviate urine blockages, phlegm, acts as diuretic, stimulant, and as an expectorant ${ }^{8}$.

A. cepa contains sugar, carbohydrates, water, proteins, vitamins, fiber, potassium, vitamin C, B6 and trace amount of mineral schromium, Onions require specific conditions for the optimal growth which include stone-free, loamy, sunlight, excellent drainage, well-irrigated soil ${ }^{9}$ with significant amounts of nitrogen, phosphorus and potassium are required for maximum yield ${ }^{10}$. Nutritional value can vary with temperature which plays an important role in onion development as in hotter conditions more sulfur and pungent flavor will be produced, sulfate fertility in soil, water supply which plays a main role in determining pungency and flavor, variety, sulfate fertility in soil, storage, environmental conditions, and flavor of it is due to sulfur compounds developing throughout the season, growth of onion under dry conditions will increases the pungent flavors ${ }^{11}$. The plant was displayed in figure -1 


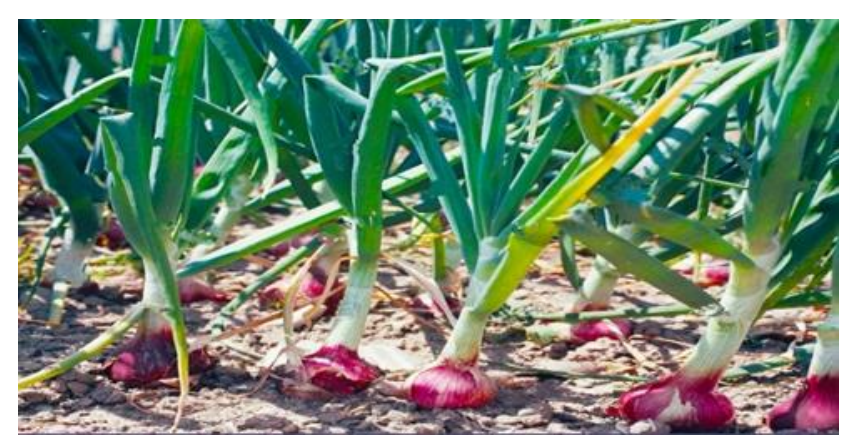

Figure 1: Entire plant of ALLIUM CEPA

\section{Plant Profile of Allium cepa}

Scientific Name: Allium cepa

Plant Family: Amaryllidaceae

English Name: Onion

Hindi Name: Palandu, piyaz

Other Names: Bulb Onion, Garden Onion, White Onion

Kingdom: Plantae

Subkingdom: Viridiplantae

Infra-Kingdom: Streptophyta (Land Plant)

Super Division: Embryophyta

Division: Tracheophyta (Vascular plants), Tracheophytes.

Sub division: Spermatophytina, Spermatophytes (seed plants).

\section{Class: Magnoliopsida}

Super Order: Lilianae (Monocots, Monocotyledons, Monocotyledones)

Order: Asparagales

Genus: Allium

Species: Allium cepa L.

Vernacular names: Onion, Basal, basl, cebolla, cebolla morada, cepa bulb, cepolla, cipolla, common onion, cu hanh, hom hua yai, Spanish onion, tamanegi, umbi bawang merah, Madras oignon, oignon, red globe onion, Zwiebel, yellow Bermuda onion, piyaj, piyaz, ralu lunu, sibuyas, loyon, etc.,

\section{Plant Description}

It is a perennial or biennial plant, grows up to $70 \mathrm{~cm}$ in both warm and cold climates, all types of soil vary from dry to moist and mineral based soils and geographically distributed in South West Asia. Shoots, seeds and bulbs are used for medicinal purpose, the roots are small and shallow roots, stems (up to $100 \mathrm{~cm}$ tall $\$ 30 \mathrm{~mm}$ diameter, tapering from inflated lower part) are stiff and erect, flowers are white to pink on the top of stem, seeds are black and small, bulb size (up to $20 \mathrm{~cm}$ in diameter), white or colored and shape (depressed-globose) may vary from cultivar to cultivar, leaves are bluish-green up to $40 \mathrm{~cm}$ (height), 20mm (diameter).Umbel $4-9 \mathrm{~cm}$ (diameter) hemispherical, dense and many flowered. Pedicels $40 \mathrm{~mm}$ and equal, filaments $4-5 \mathrm{~mm}$ outer subulate, inner expanded base nearly $2 \mathrm{~mm}$ wide, short teeth in each side, stamens are exserted. Ovary is whitish and the capsule is about $5 \mathrm{~mm}^{12,13,14}$. The parts of $A$. cepa are listed in the below fig -2

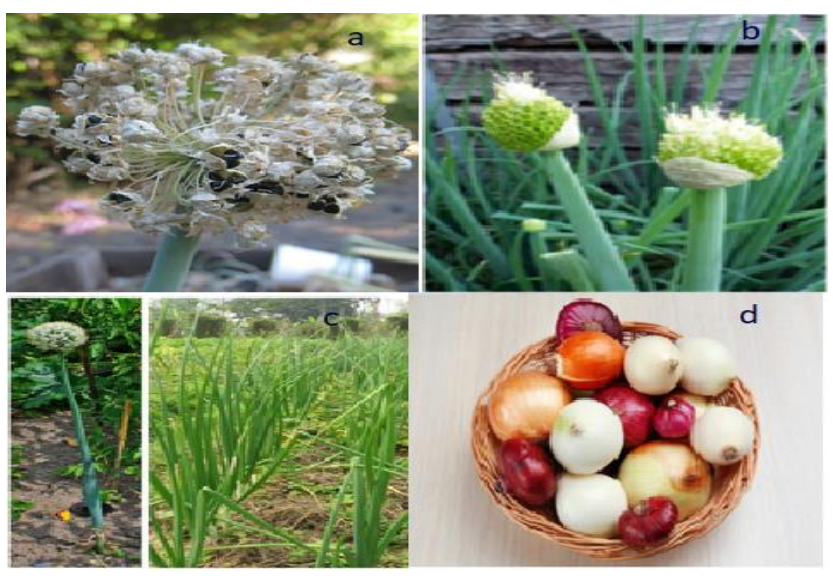

Figure 2: Parts of Allium cepa

a. Umbel with Seeds, b. Flower, c. Stem and Leaves, d. Bulbs

\section{Microscopic Characters}

The dried leaf scales of the bulbs consist a large-celled epidermis, lightly spotted cell walls, cells (elongated longitudinally), underlying hypodermis runs perpendicular to epidermis with large calcium oxalate crystals along the cell walls. For fresh leaf scales are same as dried leaf, epidermal cells dorsal side, distinctly longer, more elongated than ventral side epidermal cells, large calcium oxalate crystals in hypodermis, rare stomata, in leaf mesophyll spiral vessel elements are present and large cell nuclei $^{15}$

\section{Chemical Constituents}

A. cepa principal consistent is an important oil containing more amount of mono, di, tri, tetra-sulphides, thiophene and thiols derivatives. Bulbs and leaves of onion consist of huge number of cyaniding glycosides, prostaglandins, quercetin, other flavonoids, sterols, phenol compounds, catechol, protocatechuic acid are present in dry brown outer scale, diosgenin in flowers and bulbs ${ }^{16}$. Onions also contain selenium ${ }^{17}$, quercetin ${ }^{18}$, flavenols ${ }^{19}$, S-alk(en)yl cysteine sulfoxides 20, flavonoids, allylsulfides 21, 22, organosulfur compounds ${ }^{23}$, thiosulfinates ${ }^{24}$, cycloallin ${ }^{25}$, fructose, quercetin-3-glucoside and isohamnetin-4glucoside ${ }^{26}$, sulfur and seleno compounds ${ }^{27}$, sulfinates, xylose, galactose, glucose and mannose ${ }^{28,29}$.

\section{Pharmacological Activities}

\section{a) Antibiotic activity}

Onion exhibit antibiotic activity against both Gram-positive and Gram-negative bacteria ${ }^{30}$. The fresh raw extracts of Allium cepa possess significant antibacterial potency against the bacteria's which are resistant for antibiotic 
drugs ${ }^{31}$. Onion extracts are shown the antibacterial activity against the organisms used in the test ${ }^{32}$.

\section{b) Antiviral activity}

Onion and garlic consist huge amount of organosulphur compounds like quercetin, allicin which inhibits the viral infection and impart antiviral property ${ }^{33}$. By studying the molecular docking of that main protease of COVID-19 by the natural compounds are found in garlic and onion these can be used as a powerful prohibitors opposing the main protease of COVID-19 ${ }^{34}$.

\section{c) Antioxidant activity}

Aqueous extract of Allium cepa antioxidant activity ${ }^{35}$. Allium cepa red and white varieties showed antioxidant activities $^{36}$. Quercetin-3'-O-beta-D-glucoside isolated from Allium cepa antioxidant activities ${ }^{37}$. Onion flesh and onion peel enhance antioxidant status in aged rats 38 . Antidiabetic and antioxidant effects of S-methyl cysteine sulfoxide isolated from onions ( $A$. cepa Linn.) as compared to standard drugs in alloxan diabetic rats ${ }^{39}$. Dietary flavonols protect diabetic human lymphocytes against oxidative damage to DNA ${ }^{40}$.

\section{d) Anti-cancer activity}

Number of in vitro, animal, epidemiological studies indicate that onion extract or onion prevents cancer including gastrointestinal cancer, ovarian cancer, skin cancer $41,42,43,44$. Common current theory is that the metabolites of organosulfur, especially S-alk(en)yl cysteine sulfoxide, found in these herbs inhibits mutagenesis, incorporate phase two detoxification enzymes, influence cell arrest and apoptosis, scavenge free radicals and inhibit DNA adduct formation ${ }^{45,46}$.

\section{e) Anti-inflammatory activity}

Onion showing anti-inflammatory activity by the presence of quercetin. Onions showed antiasthmatic activity ${ }^{47}$. The natural product Ajoene is isolated from Allium shows antiinflammatory properties ${ }^{48}$. The fistular onion stalk extract useful for the attenuation of atherosclerosis and the mechanism includes the regulation of the local inflammatory response ${ }^{49}$.

\section{f) Antihyperlipidemic activity:}

Onion derived sulfur compounds including S-methyl cysteine sulfoxide and allyl propyl disulphide ${ }^{50}$, showed hypolipidemic effects. These are established in rats and rabbits, lower down effects of diet-induced atherosclerosis, maintain hypolipidemic action, inhibitory effects on platelet formation ${ }^{51}$.

\section{g) Anti-hypertensive activity}

The hydroalcoholic extract of onion peel hypotensive effect by quercetin, anti-oxidant activity and as well as inhibition of $\mathrm{Ca}^{2+}$ influx in vascular smooth muscle cells ${ }^{52}$. Hypertension study, using some rat models, has indicated that quercetin and its methylated metabolite isorhamnetin, found in onion, can reduce blood pressure and prevent angiotensin- $\mathbb{I}$-induced endothelial dysfunction by inhibiting the overexpression of p47phox, a regulatory subunit of the membrane NADPH oxidase. The subsequent increased superoxide production resulted in a high nitric oxide bioavailability ${ }^{53}$. Ethanolic extracts of onion and garlic in hypertensive rats reported that oral administration of extracts during a normal salt diet or during a high salt diet do not influence blood pressure ${ }^{54}$.

\section{h) Anti-cancer activity}

Consumption of Allium vegetables for prevention of different cancers ${ }^{55}$. Fisetin $\left(3,7,3^{\prime}, 4^{\prime}\right.$-tetrahydroxyflavone) belongs to flavonol sub group of flavonoids together with quercetin, myricetin, kaempferol is found in several fruits and vegetables including apples, onions, strawberries and persimmons. Fisetin is natural agent that shows potential inhibitory role against cancer in several in vitro and in vivo studies ${ }^{56}$. A. cepa shows the presence of quercetin- 3 '-Obeta-D-glucoside that display potent melanin biosynthesis inhibitory activity in B16 melanoma cells ${ }^{57}$. Ethanolic extract is used for the management of breast tumors ${ }^{58}$. Onion is good in controlling prostatic hypertrophy, endometrial, lung, gastrointestinal, breast related cancers 59. Natural products present in onion cause alteration in carcinogen-metabolizing enzymes, cell cycle arrest, induction of apoptotic cell death, suppression of oncogenic signal transduction pathways and inhibition of neoangiogenesis ${ }^{60}$.

\section{i) Anti-arthritic activity}

Extract of onion skin showed the prevention of arthritis principal signs and reduces joint damage caused by CFA immune-mediate modulation monoarthicular arthritis induced in rats ${ }^{61}$.

\section{j) Bronchodilator activity}

By using ex-vitro and in-vivo assays the extract of red onion showed the bronchodilator activity in guinea pig and rat tracheal study ${ }^{62}$.

\section{k) Anti-spasmolytic activity}

Flavonoid-rich hydro-acetone present in extract of red onion peel possess spasmolytic activity ${ }^{62}$. Hydroalcoholic extract of onion peel consists of spasmolytic effect on rat ileum ${ }^{63}$. High concentration of flavonoids and saponins present in red onion results anti-spasmolytic activity ${ }^{64}$.

\section{I) Expectorant activity}

Onion consists of expectorant progenies and acts as expectorant ${ }^{65,66}$. Onion comprise pharmacological activity as an expectorant ${ }^{67}$.

\section{m) Antiseptic activity}

Phytochemicals present in the onion extract consists of anti-microbial activity against food borne pathogens Escherichia coli and Staphylococcus Aureus ${ }^{68}$. 


\section{n) Anticoagulant activity}

Red onion aqueous extract has anticoagulant activity and had investigated by using the principles of prothrombin time test in In-vitro study ${ }^{69}$. Onion extract has anticoagulant property through prohibition of clot formation and coagulation process ${ }^{70}$. Extract of Allium cepa used in albino rat blood justified the anticoagulant activity of onion (A. cepa $)^{71}$.

\section{o) Fibrinolytic activity}

Onion has confirmed the fibrinolytic activity by giving fatenriched diet with and without onions in people 72 . Cycloallin which is present in onion administrated to post myocardial infraction people induced a significant increase in fibrinolysis after $15 \mathrm{~h}$ of medication ${ }^{73}$. In in vitro study of the extracts of onion and garlic, onion has plasminogen activator which acts as fibrinolytic agent without proactivator $^{74}$.

\section{p) Anti-helminthic activity}

Extracts of A. cepa, A. sativum, Jatropha curcas with water and ethanol in In vitro method against Toxocara canis and Ancylostoma caninum, onion extract has good anthelmintic activity by affecting the survival of larvae ${ }^{75}$.

\section{q) Anti-platelet activity}

Onion has antioxidant and antiplatelet activity and was observed by FC, TEAC, DPPH and Principal component analysis methods with people blood samples without medication for a week ${ }^{76}$.

\section{r) Anti-diabetic activity}

Soup of A. cepa is used for Type-2 diabetes mellitus controlling and also in other group life style diseases ${ }^{77}$. Red onion shows hypoglycemic effects of onion in Type1 and 2 diabetic patients ${ }^{78}$. Dietary bulbs of onion showed antidiabetic effect in a high fat diet streptozotocin induced diabetes rodent model $79,80,81$. Onion has hypoglycemic effect in alloxan induced diabetic rats ${ }^{82}$. The potency of onion in Hypoglycaemic and antioxidant effects ${ }^{83}$.

\section{s) Anti-genotoxic and anti-mutagenic activity}

Onion has anti-genotoxic and anti-mutagenic activity ${ }^{84}$. Impact of ozonation on the genotoxic activity of tertiary treated municipal water reduced by onion ${ }^{85}$.

\section{t) Anti-pyretic activity}

Extract of fresh onion blubs on paracetamol and tetrachloride induced hepatotoxicity ${ }^{86}$. Genotoxicity induced by series of pharmaceutical compounds, metamizole sodium and acetylsalicylic acid toxicity, genotoxicity and cytotoxicity can cut down by onion [87][88][89].

\section{u) Analgesic activity}

Powder of onion has antidepressant like effect in behavioral model of depression in rat ${ }^{90}$. Inhibition of chronic, acute pain and inflammation with fresh juice of onion and its strong effect towards inflammation ${ }^{91}$.

\section{v) Hepatoprotective activity}

Extracts of garlic and onion had potential towards hepatoprotective on cadmium-induced oxidative damage in rats ${ }^{92}$. Methanolic extract of onion has significant effect on hepatoprotective activity against paracetamol induced hepatotoxicity ${ }^{93}$.

\section{w) Neuroprotective activity}

Methanolic extract of outer scales, edible portion of $A$. cepa bulb when administrated to mice before cerebral ischemia and reperfusion exhibit notable neuroprotection by noticeably reducing cerebral infract size, remarkable decreasing, increase in thiobarbituric acid reactive substances concentration in brain mitochondria, supernatant fractions and preventing global cerebral ischemia reduced impairment of motor coordination and short term memory ${ }^{94}$.

\section{CONCLUSION}

Now a days, onion has great importance and one of the magical foods, traditional medicinal plant due to its phytoconstituents and usable vegetable. Onion contains Sulphur compounds, glycosides, quercetin, flavonoids, phenol compounds, diosgenin, organosulfur compounds, S-alk(en)yl cysteine sulfoxides, cycloallin, allylsulfides, seleno compounds and sugar, water, carbohydrates, proteins, vitamins, fiber and potassium. Onion also contain compounds manifesting different therapeutic and pharmacological activities such as antioxidant, antiinflammatory, anti-cholesterol, anti-hypertensive, anticancer, anti-arthritic, anti-bacterial, bronchodilator, antispasmodic, antiseptic, carminative, anti-coagulant, fibrinolytic, anti-helminthic, anti-platelet, anti-diabetic, anti-viral, cardiovascular protective, anti-microbial, hepatoprotective, neuroprotective, antigenotoxic, antimutagenic properties.

\section{REFERENCES}

1. Griffins G, True man L, Crowther T, Thomas B, Smith B. Onions: a global benefit to health. Phytother Res.2002; 16(7):603-615. Doi:10.1002/ptr.1222.

2. Sujanthiya $P$, Swaminathan V, Arunkumar R, Siva kumar T. Exploration on pre sowing seed invigoration with growth regulators on germination of small onion (Allium cepa var. aggregatum). International Journal of Current Microbiology and Applied Sciences. 2020; 9(8):1219-1225. Doi: https: //dio.org /10.2056/ijcmas. 2020.908.136.

3. Krishnaswamy K. Traditional Indian spices and their health significance. Asia Pac J Clin Nutr. 2008;7(Suppl 1):265-8. PMID: 18296352.

4. Sunil Pareek, Alok sagar N, Sunil Sharma, Vinay Kumar. Onion (Allium cepa L.). In book: Fruit and vegetable phytochemicals, Chemistry and Human Health. ElhadiM. Yahia, $2^{\text {nd }}$ edition. Wiley Blackwell, John Wiley and Sons Ltd; 2017. P. 1145-1161(16)).

5. Jedelska J. Pharmaceutical values of onions (Allium L.) and related species of central Asia. Paper presented: at doctoral degree of the natural sciences the department of pharmacy of the Philipps University of Marburg/ Lahn 2007, April, Sernberk, Olomouc, Czechia. 
6. Onion meaning and translation in Malayalam, Tamil, Kannada, Punjabi, Telugu. available from https://www.pachakam.com/glossarydetail/onion____ (accessed Mar.22,2021)

7. Rajesh B. Raising heat, drought in Maharashtra and southern India may hit onion prices. Mumbai, last updated at June 2019.www.business-standard.com. Available from https://images.app.goo.gl/YB7yEEwtyGju4pRA (accessed Feb. 14,2021).

8. Allium cepa L. Global Biodiversity Information Facility. Free and Open Access to Biodiversity Data. Source: World check list of selected plants. updated on 2019. www.gbif.org. available from https://www.gbif.org/species/2857697 (accessed Feb. 14,2021)

9. Ellen Spector Platt, Garlic, Onion and Other Alliums, Mechanicsburg, PA: Stackpole Books; 2003.

10. Estes J W, Staple Foods: Domesticated Plants and Animals: Onion, The Cambridge World History of Food, Ed. Kenneth F. Kiple and Kriemhild Conee Omelas: Cambridge University Press;2000.

11. Randle $\mathbf{W} \mathrm{M}$, Onion Flavor Chemistry and Factors Influencing Flavor Intensity. American Chemical Society.1997;660(1):41-52, Doi:10.1021/bk-1997-0660.ch005

12. Jagdev Singh. Onion (Allium Cepa), Its Health benefits. Updated at February 2015. Ayur times. Available from https://www.ayurtimes.com/onion-allium-cepa/_(accessed Feb. $16,2021)$

13. Tutin T G, Heywood V H, Burges N A, Moore D M, Valentine D H, Walters S M, Webb D A. Flora Europaea, vol. 5. Cambridge, Cambridge University Press; 1980.

14. Onion-Wikipedia. Available from https://en.m.wikipedia.org/wiki/Onion (accessed Jan 10, 2021).

15. Prisca anggela. WHO monographs on selected medicinal plants-Vol1. In: Bulbus Allii cepae. World health organization. Geneva ;1999. p. 5-17.

16. Herbs as health food. Herbal medicine: also called botanical medicine or phytomedicine Herbalism is a traditional medicinal or folk medicine practice. source: slideplayer.com. Available from https://images.app.goo.gl/gxBYQoMioCDRwwpF6. (accessed Feb. 17,2021)

17. Arnault I, Auger J. Seleno-compounds in garlic and onion. J. Chromatogr.2006;1112(1-2): 23-30. Doi: 10.1016/j.chroma.2006.01.036.

18. Hubbard G P, Wolffram S, de Vos R, Bovy A, Gibbins J M, Lovegrove $J$ A. Ingestion of onion soup high in quercetin inhibits platelet aggregation and essential components of the collagen-stimulated platelet activation pathway in man: a pilot study. Br. J. Nutr. 2006;96(3):482-488. Doi:10.1079/BJN20061831.

19. Noroozi M, Burns J, Crozier A, Kelly I E, Lean M E. Prediction of dietary flavonol consumption from fasting plasma concentration or urinary excretion. Eur. J. Clin. Nutr.2000; 54(2):143-149. Doi: 10.1038/sj.ejcn.1600908.

20. Rose $\mathrm{P}$, Whiteman $\mathrm{M}$, Moore $\mathrm{P} \mathrm{K}$, Zhu Y Z. Bioactive S-alk(en)yl cysteine sulfoxide metabolites in the genus Allium: the chemistry of potential therapeutic agents. Nat. Prod. Rep. 2005;22(3):351-368. Doi: 10.1039/b417639c.

21. Sengupta A, Ghosh S, Bhattacharjee $\mathrm{S}$. Allium vegetables in cancer prevention: an overview. Asian Pac. J Cancer. Prev.2004;5(3):237245. PMID: 15373701

22. Heber D, Bowerman S. Applying science to changing dietary patterns. J. Nutr.2001; 131(11 Suppl):3078S-3081S. Doi: 10.1093/jn/131.11.3078S

23. Fukushima S, Takada N, Hori T, Wanibuchi H. Cancer prevention by organosulfur compounds from garlic and onion. J. Cell Biochem. Suppl. 1997; 27:100-105. PMID: 9591199.

24. Augusti K T. Therapeutic values of onion (Allium cepa L.) and garlic (Allium sativum L.). Indian J. Exp. Biol. 1996;34(7):634-640. PMID: 8979497.
25. Agarwal R K, Dewar H A, Newell D J, Das B. Controlled trail of the effect of cycloalliin on the fibrinolytic activity of venous blood. Atherosclerosis.1977;27(3):347-351. Doi: 10.1016/00219150(77)90044-2.

26. Boyle S P, Dobson V L, Duthie S J, Collins A R. Absorption of DNA protective effects of flavonoid glycosides from an onion meal. Eur. J. Nutr.2000;39(5):213-223, Doi: 10.1007/s003940070014.

27. Baraboi $V$ A, Shestakova E N. Selenium: the biological role and antioxidant activity. Ukr.Biokhim.Zh.2004;76(1):23-32. PMID: 15909414.

28. Lanzotti V. The analysis of onion and garlic. J. Chromatogr A.2006;1112(1-2):3-22. Doi: 10.1016/j.chroma.2005.12.016.

29. Gibson $\mathrm{G}$ R. Dietary modulation of the human gut microflora using prebiotics. Br. J. Nutr.1998;80(4): S209-S212. PMID: 9924286.

30. Sivam G P. Protection against Helicobacter pylori and other bacterial infections by garlic. J. Nutr. 2001; 131(3s):1106S-1108S. Doi: 10.1093/jn/131.3.1106S.

31. Zikora Anyaegbunam K, Ogara Amaechi L, Anyaegbunam Tito C, Oniwon Wisdom O, Ogechukwu Henrietta C, Cosmas S, Ofoefule Sabinus I. Antibacterial Activity of Fresh Red and White Onion (Allium cepa) Extract against Some Drug Resistant Bacteria. JAMB.2019;16(4):1-8. Doi: 10.9734/jamb/2019/v16i430127.

32. Ahmed M K, Hani S F, Ahmad M A, Safaa A T. Antibacterial Effect of Onion. Sch. J. App. Med. Sci. 2016; 4(11D): 4128-4133. Doi: 10.21276/sjams.2016.4.11.53.

33. Neha Sharma. Efficacy of Garlic and Onion against virus. IJRPS. 2019; 10(4): 3578-3586. Doi: 10.26452/ijrps.v10i4.1738.

34. Pratibha Pandey, Fahad Khan, Ambuj Kumar, Anshika Srinivastava, Niraj Kumar Jha. Screening of potent Inhibitors Against 2019 Novel Coronavirus (Covid-19) from Alliumsatium and Allium cepa: An inSilico Approach. Biointerface Research in Applied Chemistry.2021; 11(1):7981-7993. Doi: 10.33263/BRIAC111.79817993.

35. Kumar K E, Harsha K N, Sudheer V, Nelli G B. In vitro antioxidant activity and in vivo hepatoprotective activity of aqueous extract of Allium cepa bulb in ethanol induced liver damage in Wistar rats. Food Sci Hum Wellness. 2013; 2:132-138. Doi: 10. 1016/j.fshw.2013.10.001

36. Benmalek Y, Yahia O A, Belkebir A, Fardeau M L. Anti-microbial and anti-oxidant activities of Illicium verum, Crataegus oxyacantha ssp monogyna and Allium cepa red and white varieties. Bioengineered.2013; 4(4):244-48. Doi: 10.4161/bioe.24435.

37. Yang J, Meyers K J, van der Heide J, Liu R H. Varietal differences in phenolic content and antioxidant and antiproliferative activities of onions. J Agric Food Chem. 2004;52(22):6787-93. Doi: 10.1021/jf0307144.

38. Di Renzo L, Di Pierro D, Bigioni M, Sodi V, Galvano F, Cianci R, La Fauci L, De Lorenzo A. Is antioxidant plasma status in humans a consequence of the antioxidant food content influence. Eur Rev Med Pharmacol Sci. 2007; 11(3):185-92. PMID: 17970235.

39. Kumari K, Augusti K T. Antidiabetic and antioxidant effects of Smethyl cysteine sulfoxide isolated from onions (Allium cepa Linn) as compared to standard drugs in alloxan diabetic rats. Indian J Exp Biol. 2002; 40(9):1005-9. PMID: 12587728.

40. Lean M E, Noroozi M, Kelly I, Burns J, Talwar D, Sattar N, Crozier A. Dietary flavonols protect diabetic human lymphocytes against oxidative damage to DNA. Diabetes.1999; 48(1):176-181. Doi: 10.2337/diabetes.48.1.176

41. Troll W. Protease inhibitors interfere with the necessary factors of carcinogenesis. Environ Health Perspect. 1989; 81:59-62. Doi: 10.1289/eph.898159.

42. Wargovich M J. New dietary anticarcinogens and prevention of gastrointestinal cancer. Dis colon Rectum. 1988; 31(1):72-5. Doi: 10.1007/BF02552576.

43. Gonzalez Carlos A, Guillem Pera, Antonio Agudo, H Bas Bueno-deMesquota, Marco Ceroti, Heiner Boeing, Mandy Schulz, Guiseppe Del Giudice, Mario plebani, Fatima Carlotta Sacerdote, Rosario 
Tumino, Salvartore Panico, Goran Berglund, Henrik Siman, Goran Hallmans, Roger Stenling, Carmen Martinez, Miren Dorronsoro, Aurelio Barricarte, Carmen Navarro, Jose R Quiros, Naomi Allen, Timothy J Key, Sheila Bingham, Nicholas E Day, Jakob Linseisen, Gabriele Nagel, Kim Overvad, Majken K Jensen, Anja Olsen, Anne Tjonneland, Frederike L Buchner, Petra H M Peeters, Mattijs E Numans, Francoise Clavel-Chapelon, Marie-Christine BoutronRault, Dimitrios Roukos, Antonia Trichopoulou, Theodora Psaltopoulou, Eiliv Lund, Corinne Casagrande, Nadia Slimani, Mazda Jenab, Elio Riboli. Fruit and vegetable intake and the risk of stomach and oesophagus adenocarcinoma in the European Prospective Investigation into Cancer and Nutrition (EPIC-EURGAST). Int J Cancer. 2006; 118(10):2559-66. Doi :10.1002/ijc.21678.

44. Schulz Mandy, Lahmann Petra H, Boeing Heiner, Hoffmann Kurt, Allen Naomi, Timothy J A Key, Bingham Sheila, Wirfalt Elisabet, Berglund Goran, Lundin Eva, Hallmans Goran, Annekatrin Lukanova, Martinez Garcia Carmen, Gonzalez Carlos A, Tormo Maria J, Jose R Quiros, Eva Ardanaz, Nerea Larranaga, Eiliv Lund, Inger T Gram, Guri Skeie, Petra H M Peeters, Carla H van Gills, H Bas Bueno-deMesquita, Frederike L Buchner, Patrizia Pasanisi, Rocco Galasso, Domenico Palli, Rosario Tumino, Paolo Vineis, Antonia Trichopoulou, Victoria Kalapothaki, Dimitrios Trichopoulos, Jenny Chang-Claude, Jakob Linseisen, Marie Christine Boutron-Ruault, Marina Touillaud, Francoise Clavel-Chapelon, Anja Olsen, Anne Tjonneland, Kim Overvad, Mette Tetsche, Mazda Jenad, Teresa Norat, Rudolph Kaaks, Elio Riboli. Fruit and vegetable consumption and risk of epithelial ovarian cancer: the European Prospective Investigation into Cancer and Nutrition. Cancer Epidemiol Biomarkers Prev.2005; 14(11Pt 1): 2531-5. Doi: 10.1158/10559965.EPI-05-0159.

45. Srinivasan K. Plant foods in the management of diabetes mellitus: spices as beneficial antidiabetic food adjuncts. Int J Food Sci Nut. 2005;56(6):399-414. Doi: 10.1080/09637480500512872.

46. David Heber. Vegetables, fruits and phytoestrogens in the prevention of diseases. J Postgrad Med.2004; 50(2)145-9. PMID: 1523216.

47. Dorsch W, Schneider E, Bayer T, Breu W, Wagner H. Antiinflammatory effects of onions: inhibition of chemotaxis of human polymorphonuclear leukocytes by thiosulphates and cepaenes. Int Arch Allergy Appl Immunol.1990; 92(1):39-42. Doi: 10.1159/000235221.

48. Dirsch V M, Vollmar A M. Ajoene, a natural product with nonsteroidal anti-inflammatory drug (NSAID)-like properties. Biochemical Pharmacology. 2001;61(5): 587-593. Doi: 10.1016/s0006-2952(00)00580-3.

49. Benhong He, Jianjun Hao, Weiwei Sheng, Yuancai Xiang, Jiemeia Zhang, Hao Zhu, Jingcheng Tian, Xu Zhu, Yunxia Feng, Hao Xia. Fistular onion stalk extract exhibits anti-atherosclerotic effects in rats. Exp Ther Med. 2014; 8(3): 785-792. Doi: 10.3892/etm.2014.1790.

50. Kumari K, Augusti K T. Lipid lowering effect of S-methyl cysteine sulfoxide from Allium cepa Linn in high cholesterol diet fed rats. J Ethnopharmacol.2006; 10.1016/j.jep.2006.07.045.

51. Augusti K T, Arathy S L, Asha R, Ramakrishanan J, Zaira J, Lekha V, Smitha $S$, Vijayasree $V M$. A comparative study on the beneficial effects of garlic (Allium sativa Linn), amla (Emblica Officinalis Gaertn) and onion (Allium cepa Linn) on the hyperlipidemia induced by butter fat and beef fat in rats. Indian J Exp Biol.2001; 39(8):76066. PMID: 12018576.

52. Kazem Gharib Naseri Mohammad, Arabian Maedeh, Badavi Mohammad, Ahangarpour Akram. Vasorelaxant and Hypotensive Effects of Allium Cepa peel hydroalcoholic Extract in rat. Pakistan Journal of Biological Sciences.2008;11(12): 1569-1575. Doi: 10.3923/pjbs.2008.1569.1575.

53. Sanchez Manuel, Lodi Federica, Vera Rocio, Villar Inmaculada C, Cogolludo Angel, Jimenez Rosario, Moreno Laura, Romero Miguel, Tamargo Juan, Perez-Vizcaino Francisco, Duarte Juan. Quercetin and Isorhamnetin prevent endothelial dysfunction, Superoxide production, and overexpression of $\mathrm{p} 47^{\text {phox }}$ induced by Angiotensin II in Rat Aorta. The Journal of Nutrition. 2007; 137(4): 910-915. Doi: 10.1093/jn/137.4.910.

54. Kivirantat Jair, Huovinen Keijo, Seppanen-Laakso Tuulikki, Hiltunen Raimo, Karppanen, Kilpelainen Heikki Mikko. Effects of onion and garlic extracts on spontaneously hypertensive rats. Phytotheraphy Research. 1989; 3(4): 132-135. Wiley online library. https://doi.org/10.1002/ptr.2650030404.

55. Holly L Nicastro, Sharon A Ross, John A Milner. Garlic and onions: Their cancer prevention properties. Cancer Prev Res (Phila).2015; 8(3):181-189.Doi: 10.1158/1940-6207.CAPR-14-0172.

56. Weidmann Anita Elaine. Dihydroquercetin: More than just an impurity. Eur J Pharmacol.2012; 684(1-3):19-26. Doi: 10.1016/j.ejphar.2012.03.035.

57. Arung Enos Tangke, Furuta Shoko, Ishikawa Hiroya, Shimizu Kuniyoshi, Kondo Ryuichiro. Melanin biosynthesis inhibitory and antioxidant activities of quercetin-3'-O-beta-D-glucoside isolated from Allium cepa. Z Naturforsch C J Biosci.2011; 66(5-6): 209-14. Doi: 10.1515/znc-2011-5-603.

58. Oloyede A, Okpuzor J, Omidiji O. Cytological and toxicological properties of a decoction used for managing tumors in Southwestern Nigeria. Pak J Biol Sci.2009;12 (4):383-7. Doi: 10.3923/pjbs.2009.383.387.

59. Yong Zhou, Wen Zhuang, Wen Hu, Guan- Jian Liu, Tai-Xiang Wu, Xiao-Ting Wu. Consumption of large amounts of Allium vegetables reduces risk for gastric cancer in a meta-analysis. Gastroenterology. 2011;141(1): 80-9. Doi: 10.1053/j.gastro.2011.03.

057.

60. Pham Anh, Bortolazzo Anthony, Brando White J. Rapid dimerization of quercetin through an oxidative mechanism in the presence of serum albumin decreases its ability to induce cytotoxicity in MDAMB-231 cells. Biochem Biophys Res Commun.2012; 427(2): 415-20, Doi: 10.1016/j.bbrc.2012.09.080.

61. Aiman Ummu, Khatimah Husnul, Ariiq Saifullah Muhammad, Carnegie Matondang Muhammad, Sukmana Dike Dandari, Anderiani Miskad Upik. Anti-Arthritic effect of onion skin extract on rat complete Freund's adjuvant-induced. European Journal of Molecular and Clinical Medicine. 2020;7(7): 1183-92, 2020.ISSN 2515-8260.

62. Mandukhali Saf-ur-Rehman, Ahmed Atallah F, Al-Yousef Hanan M, Al-Qahtani Jawaher Hamad, Gilani Anwarul-Hassan. The mechanism underlying the spasmolytic and bronchodilatory activities of the flavonoid -rich red onion "Allium cepa L." peel Extract. International Journal of Pharmacology.2014;10(2):82-89. Doi:10.3923/ijp.2014.82-89.

63. Kazem Gharib Naseri Mohammad, Yahyavi Hoda, Arabian Maedeh. Antispasmodic Activity of Onion (Allium cepa L.) peel Extract on Rat Ileum. Iranian Journal of Pharmaceutical Research.2008;7(2):155159. Doi:10.22037/IJPR.2010.759.

64. Gabriella Corea, Ernesto Fattorusso, Virginia Lanzotti, Raffaele Capasso, Angelo A. Izzo. Antispasmodic saponins from Bulbs of Red onion, Allium cepa L. var. Tropea. Journal of Agricultural and Food

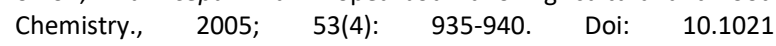
/jf048404o.

65. Sampath Kumar K P, Bhowmik Debjit, Chiranjib, Biswajit, Pankaj Tiwari, "Allium cepa: A Traditional medicine herb and its health benefits. Journal of Chemical and Pharmaceutical Research.2010; 2(1):283-291. Available from www.jocpr.com. ISSN no:0975-7384.

66. Medicinal uses of onion. Available from Sypdersden WordPress.com. https://images .app.goo.gl/mH72ULWMCwZXCEaRA (accessed Mar. 22,2021)

67. Virshette $S \mathrm{~J}$, Patil $M \mathrm{~K}$, Shaikh Junaid $\mathrm{R}$. A review on pharmacological properties and phytoconstituents of indigenous carminative agents. Journal of Pharmacognosy and Phytochemistry.2020;9(3):142-145. www.phytojournal.com.

68. Marsunn Ortiz. Antimicrobial activity of onion ang ginger against two food borne pathogens Escherichia coli and staphylococcus 
Aureus. MOJ Food Process Technol. 2015;1(4):104-112. Doi: 10.15406/mojfpt.2015.01.00021.

69. Mansoor Al-Saadi Narjis Hadi. In vitro study of the anticoagulant activity of some plant extracts. Indian Journal of Applied Research.2013;3(7):120-122. Doi: 10.36106/ijar.

70. Taj Eldin I $M$, Abdalmutalab Majed $M$, Izzalddeen Hajir $M$, Abdalkareem Madina A, Abdalraheem Marwa A, Alhassan Marwa B. Evidence for an in vitro Anticoagulant Activity of Red onion (Allium cepa L.). Sudan JMS.2011; 6(2): 85-88. Doi: 10.4314/sjms. v6i2.72459.

71. Ebbo A. A, Bello A, Ismail S M, Liman Y M, Idris S B, Ogah J I, Sani A. A, Yusuf S A. In Vitro Anticoagulant Effects of Aqueous Extract of Allium cepa (onion) on Albino Rat Blood. Chronicles of Pharmaceutical Science.2019; 4(1): 4-9. Scientiaricerca.com.

72. Sudhakaran Menon I, Kendal R Y, Dewar H A, Newell D J. Effect of Onions on Blood Fibrinolytic Activity. Brit. med. J.1968; 3(5614): 351-352. Doi:10.1136/bmj.3.5614.351.

73. Agarwal R K, Dewar H A, Newell D J, Das B. Controlled trail of the effect of cycloalliin on the fibrinolytic activity of venous blood. Atherosclerosis.1977; 27(3):347-51. Doi: 10.1016/00219150(77)90044-2.

74. Nagda K. K, Ganeriwal S K, Nagda K C, Diwan A M. Effect of onion and garlic on blood coagulation and fibrinolysis in vitro. Ind. J. Physiol. Pharmac.1983; 27(2):141-45. PMID: 6885127.

75. Orengo $\mathrm{K} \mathrm{O}$, Maitho $\mathrm{T}$, Mbaria J $\mathrm{M}$, Maingi $\mathrm{N}$, Kitaa J $\mathrm{M}$. In vitro anthelmintic activity of Allium sativum, Allium cepa, and Jatropha curcas against Toxocara canis and Ancylostoma caninum. African Journal of Pharmacy and Pharmacology. 2016;10(21): 465-71. Doi: 10.5897/AJPP2016.4551.

76. Aniela Saplontai-Pop, Augustin Mot, Marioara Moldovan, Radu Oprean, Radu Silgahi Dumitrescu, Olga Orasan, Marcel Parvu, Emese Gal, Corina lonescu. Testing antiplatelet and antioxidant activity of the extract of seven varieties of Allium cepa L. Open Life Sci.2015; 10(1): 89-98. Doi: 10.1515/biol-2015-0011.

77. Ebrahimi-Mamaghani Mehranghiz, Saghafi-Asl Maryam, Pirouzpanah Saeed, Asghari-Jafarabadi Mohammad. Effects of raw onion consumption on metabolic features in overweight or obese women with polycystic ovary syndrome: a randomized controlled clinical trial. J Obstet Gynaecol Res.2014; 40(4):1067-76. Doi: 10.1111/jog.12311.Epub 2014 Mar 10.

78. Abhishek Bhanot, Richa Shri. A comparative profile of methanol extracts of Allium cepa and Allium sativum in diabetic neuropathy in mice. Pharmacognosy Res.2010; 2(6): 374-84. Doi:10.4103/09748490.75460 .

79. Bang Mi-Ae, Kim Hyeon-A, Cho Young-Ja. Alterations in the blood glucose, serum lipids and renal oxidative stress in diabetic rats by supplementation of onion (Allium cepa. Linn). Nutr Res Pract.2009; 3(3): 242-6, Doi: 10.4162/nrp.2009.3.3.242.

80. Kook Sejeong, Kim Gun-Hee, Choi Kiheon. The antidiabetic effect of onion and garlic in experimental diabetic rats: meta-analysis. J Med Food.2009; 12(3): 552-60. Doi: 10.1089/jmf.2008.1071.

81. Gabriela Tataringa, Anca Miron, loana Paduraru, Monica Hancianu, Eliza Gafitanu, Ursula Stanescu. Characterization of some extractive fractions isolated from raw Allium cepa L. bulbs. Rev Med Chir Soc Med Nat lasi. 2008;112(2): 522-4. PMID:192950.
82. Jelodar G A, Maleki M, Motadayen M H, Sirus S. Effect of fenugreek, onion and garlic on blood glucose and histopathology of pancreas alloxan-induced diabetic rats. Indian J Med Sci.2005; 59(2): 64-9. Doi: 10.4103/0019-5359.13905.

83. Campos K E, Diniz Y S, Cataneo A C, Faine L A, Alves M J Q F, Novelli $E L B$, Hypoglycaemic and antioxidant effects of onion, Allium cepa: dietary onion addition, antioxidant activity and hypoglycaemic effects on diabetic rats. Int J Food Sci Nutr.2003; 54(3):241-6. Doi: 10.1080/09637480120092062.

84. Ban Jung Ok, Hwang In Guk, Kim Tae Myoung, Hwang Bang Yeon, Lee Ung Soo, Jeong Heon-Sang, Yoon Young Won, Kimz Dae Joong, Hong Jin Tae. Anti-proliferate and pro-apoptotic effects of 2,3dihydro-3,5-dihydroxy-6-methyl-4H-pyranone through inactivation of NF-kappaB in human colon cancer cells. Arch Pharm Res.2007; 30(11): 1455-63. Doi:10.1007/BF02977371.

85. Katrin Sak. Site-specific anticancer effects of dietary flavonoid quercetin. Nutr Cancer.2014; 66(2): 177-93. Doi: 10.1080/01635581.2014.864418

86. Porchezhian E, Ansari S H. Effect of liquid extract from fresh Abutilon indicum leaves and Allium cepa bulbs on paracetamol and carbontetrachloride induced hepatotoxicity. Pharmazie.2000; 55(9): 702-3. PMID: 11031781

87. Tulay Askin Celik, Ozlem Sultan Aslanturk. Evaluation of cytotoxicity and genotoxicity of Inula viscosa leaf extracts with Allium test. J Biomed Biotechnol.2010;2010,18252. Doi:10.115/2010/189252.

88. Aganovic-Musinovic Izeta, Todic Maida, Becic Fahir, Kusturica Jasna. Genotoxicity evaluation of paracetamol applying Allium test. Med Arh. 2004;58(4):206-9. PMID: 15526585.

89. Arkhipchuk V. V, Goncharuk V. V, Chernykh V. P, Maloshtan L. N, Gritsenko I. S. Use of a complex approach for assessment of metamizole sodium and acetylsalicylic acid toxicity, genotoxicity and cytotoxicity. J Appl Toxicol.2004; 24(5): 401-7. Doi: 10.1002/jat.1027.

90. Hiroyuki Sakakibara, Saki Yoshino, Yoshichika Kawai, Junji Terao. Antidepressant-Like Effect of Onion (Allium cepa L.) Powder in a Rat Behavioral Model of Depression. Bioscience Biotechnology and Biochemistry.2008;72(1):94-100. Doi: 10.1271/bbb. 70454.

91. Simra Nasri, Mahdieh Anoush, Narges Khatami. Evaluation of analgesic and anti-inflammatory effects of fresh onion juice in experimental animals. African Journal of Pharmacy and Pharmacology.2012; 6(23): 1679-1684. Doi: 10.5897/AJPP12.179.

92. Obioha U E, Suru Stephen M, Ola-Mudathir Kikelomo F, Faremi Toyin $\mathrm{Y}$. Hepatoprotective potentials of onion and garlic extracts on cadmium-induced oxidative damage in rats. Bio Trace Elem Res.2009; 129(1-3): 143-56. Doi: 10.1007/s12011-008-8276-7.

93. Ozougwa J C, Eyo J E. Hepatoprotective effects of Allium cepa (onion) extracts against paracetamol-induced liver damage in rats. African Journal of Biotechnology .2014; 13(26): 2679-2688. Doi: 10.5897/AJB2014.13815

94. Richa Shri, Kundan Singh Bora. Neuroprotective effect of methanolic extracts of Allium cepa on ischemia and reperfusion-induced cerebral injury. Fitoterapia. 2008;79(2): 86-96. Doi: 10.1016/j.fitote.2007.06.013

Source of Support: None declared.

Conflict of Interest: None declared.

For any question relates to this article, please reach us at: editor@globalresearchonline.net

New manuscripts for publication can be submitted at: submit@globalresearchonline.net and submit_ijpsrr@rediffmail.com 